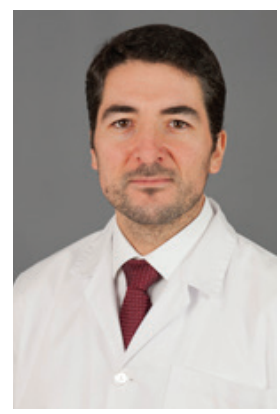

\title{
Educação Médica Contínua: Um Apelo com Grandes Desafios
}

\section{Continuing Medical Education: An Appeal with Big Challenges}

\author{
João Maia Silva
}

É com enorme satisfação que participo em mais um número da Gazeta Médica, desta feita, na redação do seu editorial.

Este número da Gazeta Médica, à semelhança dos anteriores, inclui artigo de investigação original, de revisão temática e casos clínicos, abrangendo áreas muito diversas do conhecimento médico/cirúrgico. Por este motivo, atrevo-me a dizer que este número da Gazeta Médica é mais uma excelente demonstração da importância que este modelo de edição científica tem na Educação Médica Contínua de todos nós.

É aceite por todos que a Educação Médica Contínua é indispensável para o exercício responsável da Medicina. Embora a melhor forma de organizar e estimular esta aprendizagem seja assunto largamente debatido, exemplos como a Gazeta Médica deixam-nos muito otimistas quanto ao caminho a seguir.

A Educação Médica Contínua e a atualização adequada dos elementos da classe médica tem três condicionantes essenciais. Em primeiro lugar, por parte de cada médico uma boa dose de vocação, determinação e inconformismo salutar. Em segundo lugar, por parte das instituições promotoras a capacidade concretizadora, idoneidade e seriedade são base essencial. Ambas estão inquestionavelmente presentes na José de Mello Saúde atendendo ao número, qualidade e interesse suscitado pelas iniciativas de Educação Médica Contínua, como é bom exemplo a Gazeta Médica. Em terceiro lugar, a sociedade deve definir meios de defesa contra uma eventual estagnação dos conhecimentos médicos, o que deve merecer de todos nós acompanhamento atento.

Nos últimos anos, tem-se observado uma tendência para a Educação Médica Contínua se centrar na medicina baseada na evidência, negligenciando uma vertente mais humanista do exercício da medicina que valorize, entre outras, a relação Médico-Doente. A meu ver, este fenómeno coloca alguns desafios à Educação Médica Contínua que enumero sem que a ordenação represente uma tentativa de Ihes dar importância relativa.
1. Necessidade de educar os estudantes, internos e médicos especialistas para a prática da medicina centrada na relação Médico-Doente como pilar primeiro e fundamental do exercício da Medicina como uma Arte.

2. Encontrar equilíbrio adequado entre uma abordagem científica/fisiopatológica e uma abordagem baseada na evidência. A ênfase atual nos cuidados baseados na evidência deve ser integrada com, em vez de substituir, uma base sólida nos princípios científicos e fisiopatológicos subjacentes à medicina clínica.

3. Fomentar uma cultura nos estudantes, internos e médicos especialistas que estimule a prática de medicina solidária em áreas de maior necessidade socioeconómica ou dirigidas para grupos de doentes mais desfavorecidos, conferindo o reconhecimento adequado.

4. Preparar o corpo clínico para o trabalho em equipa. A medicina está a tornar-se cada vez mais num "desporto de equipa", e os médicos devem estar bem treinados para trabalharem em equipas empenhadas em oferecer um atendimento de alta qualidade centrado no doente.

5. Desenvolver um sistema de financiamento da Educação Médica Contínua que evite a perceção de viés por interesses comerciais.

Fecho o editorial salientando que a Gazeta Médica, ao longo dos seus anos de existência, tem conseguido dar resposta a muitos destes desafios criando um ambiente que permite aos médicos refletirem e partilharem aspetos da sua prática diária. É modelo de aprendizagem e melhoria contínua, e estou certo que, no futuro, faremos muito mais e ainda melhor!!!

Deixo-vos "degustar" mais este número da Gazeta Médica na certeza que vão apreciar cada artigo.

Forte abraço João Maia Silva 